\title{
Impact of Lowering Menarchial Age on Human Embryogenesis
}

\section{Gupta PD ${ }^{1 *}$ and Pushkala K ${ }^{2}$}

${ }^{1}$ Manipal University, Manipal, Karnataka, India

${ }^{2}$ SDNB Vaishnav Collage, Chennai, Tamilnadu, India

\section{Opinion}

Recent trends in lowering of menarchial age have drawn the attention of reproductive biologist to assess its impact on future human population. Several epidemiological survey indicates a trend towards early menarche worldwide than compare to even half a century ago (Table 1). Cumulative effect of several factors such as geographical location, recent climatic changes, genetic, ethnicity, change in the life style, obesity, diet and nutrition, socioeconomic background and exposure to polluted environmental have been attributed to early menarche. The nightlights due to industrialisation exposure to extended photoperiods girls attain maturity at the age of 7-12 years in countries closer to equator (Africa). Our study indicated that there is a lowering of average age at menarche has reached to 9 years from 14 years in less than half a century.

The cascade of reproductive endocrine glands start working on onset of menarche however associated tissues and organs which are independent of steroid hormone action and are involved though albeit in up keeping of development of embryo are not ready to contribute fully towards tender age during pregnancy. Thus early reproductive maturation may not prepare an ideal environment for the pregnancy and subsequent nurturing of the baby. Estrogen and progesterone (the 2 ovarian hormones responsible for regulating menstrual cycle) stimulates growth of the uterus (and vascularity of the endometrium) and growth of the breast, widening of the pelvis, and increase regional adipose tissue - the necessary factors for successful pregnancy and its outcome are not reached at the peak.

During pregnancy the remodelling of the different systems follows including mental faculty. These changes are necessary to assist fetal development and prepare the body for labour. A study suggested that the absence of pubertal development by age 14 is associated with a high probability of conditions with impaired reproductive potential. In precocious puberty before the full development of different systems, reproductive maturity is attained such as full breast development is not over before pregnancy for further remodelling to suckle the baby soon after delivery.

The ideal menarchial age as suggested by reproductive biologist will pave the way for the best output by the cooperation and contribution of associated reproductive glands with their secretions during gestation. However, some of the factors responsible for the lowering the menarcheal age cannot be controlled and the only remedial measure is not to get pregnant soon after the menarcheal periods.

\begin{tabular}{|c|c|c|c|c|}
\hline \multirow{2}{*}{$\begin{array}{c}\text { Age Group (Starting age of } \\
\text { menarche) }\end{array}$} & \multicolumn{2}{|c|}{ Survey from age up to 20 years Girls (N=215) } & \multicolumn{2}{|c|}{ Survey from age $\mathbf{4 0 - 6 0}$ years Girls (N=150) } \\
\cline { 2 - 5 } & $\mathbf{A ~ ( \% )}$ & $\mathbf{B ~ ( \% )}$ & $\mathbf{A}(\%)$ & 0 \\
\hline $\begin{array}{c}\text { Up to Age 11 } \\
\text { years }\end{array}$ & 26 & 12.4 & 0 & 0 \\
\hline Between age 12-13 years & 178 & 82.5 & 150 & 0 \\
\hline Age beyond 13 years & 11 & 5.1 & 100 \\
\hline
\end{tabular}

Table 1: Age distribution of Menarche (within 50 years at least $12 \%$ showed very early and $80 \%$ showed early menarche: A-Number of Girls started menarche, B-Percentage (\%).

*Corresponding author: Gupta PD, Manipal University, Manipal, Karnataka, India, Tel: 97881922759; E-mail: pdg2000@hotmail.com

Received March 27, 2018; Accepted April 02, 2018; Published April 07, 2018

Citation: Gupta PD, Pushkala K (2018) Impact of Lowering Menarchial Age on Human Embryogenesis. Human Genet Embryol 8: 148. doi:10.4172/21610436.1000148

Copyright: $\odot 2018$ Gupta PD, et al. This is an open-access article distributed under the terms of the Creative Commons Attribution License, which permits unrestricted use, distribution, and reproduction in any medium, provided the original author and source are credited. 